\title{
TINJAUAN KLASIK-MODERN HUKUM ISLAM TERHADAP AIR
}

\section{Muhammad Taufan Djafri}

\author{
Sekolah Tinggi Ilmu Islam dan Bahasa Arab (STIBA) Makassar, \\ Jl. Inspeksi PAM Manggala-Antang Makassar \\ E-Mail :taufan@stiba.ac.id
}

\begin{tabular}{ll}
\hline Keywords : & \multicolumn{1}{c}{ ABSTRACT } \\
\cline { 2 - 3 } water, buman, life & Water as the artery of human life does not only fulfill the basic physical \\
& needs, but also to fulfill the primary needs of the moslem in terms of \\
& worship. Islam manages the manner of water use which is the part of \\
& the noble syari'ah. The figh of water bas been studied by the svbolars \\
& in detail, but as the time goes by and as the needs of water growing, \\
& there bave been many innovation and discovery to address increasing \\
& massive needs of water. The comparison of classical study in a modern \\
& method becomes an essential thing in determining the law. The result \\
& of this discussion will be able to provide solution for water use in the \\
& modern era.
\end{tabular}




\section{PENDAHULUAN}

Allah itu bersih dan suci، untuk menemuinya, manusia harus terlebih dahulu bersuci atau disucikan.Allah mencintai sesuatu yang bersih dan suci. Dalam hukum Islam bersuci dan segala seluk beluknya adalah termasuk bagian ilmu dan amalan yang penting terutama dijadikannya sebagai syarat-syarat sahnya salat, bahwa seseorang yang akan melaksanakan salat diwajibkan bersuci terlebih dahulu dari hadas dan najis, baik badan, pakaian dan tempatnya.

Allah swt. telah memuliakan air, ketika ia menjadikannya sebagai poros kehidupan di bumi, menjadikannya sebagai sesuatu yang suci, menghubungkannya dengan berbagai macam ibadah.

Namun Pertumbuhan penduduk yang semakin banyak mengakibatkan berkurangnya laju air bersih dari sungai dan mulai berkurangnya jumlah mata air terkhusus di kota-kota besar.Jalan yang ditempuh selanjutnya adalah dengan melakukan pencarian mata air melalui bor-bor mata air pengganti sumur.

Di dunia modern ini, ditemukan teknologi baru yang dapat melakukan daur ulang dari air yang tercemar bahkan mutanajis menjadi air yang bersih dan seteril dan secara klinis layak dikonsumsi. Adapun di dalam Islam telah dijelaskan tentang penggunaan air dalam bersuci, air yang mutanajjis tidak boleh digunakan sebagai alat bersuci.Lalu bagaimana

${ }^{1}$ Hasan bin Ahmad bin Muhammad bin Sālim Al-Kāf, al-Taqrīrāt al-Sadīdah fi Masā'il alMufídah; Qism al-'Ibādāt (Cet. I; Tarīm: Dār al-'Ilm wa al-Da'wah, $1423 \mathrm{H} / 2003 \mathrm{M}$ ), h. 57.

2'lbrahim Al-Baijūrī, Hasyiyah Al-Baijūrī, Juz 1 (Cet. II; Bairūt: Dār Al-Kutub al-'Ilmiyyah, dengan air yang sudah dilakukan daur ulang dan dianggap bersih, apakah boleh digunakan sebagai alat bersuci? Masalah inilah yang akan dibahas dalam makalah ini.

Berdasarkan latar belakang masalah dan dasar pemikiran menurut pokok masalah yaitu: Bagaiman tinjauan hukum Islam terhadap air? Maka dirumuskan dua sub masalah sebagai berikut:

1. Bagaimana macam-macam air dan pembagiannya dalam hukum Islam?

2. Bagaimana hukum air hasil daur ulang dari air limbah dan mutanajjis?

\section{PEMBAHASAN}

\section{Macam-Macam Air Menurut Hukum Islam}

Air adalah suatu benda cair yang lunak dan transparan yang berwarna dengan warna tempatnya dan Allah menciptakannya untuk menghilangkan haus dahaga. ${ }^{1}$

Air terkait dengan hukumnya untuk digunakan bersuci para ulama membaginya menjadi beberapa keadaan. Ulama membagi air menjadi beberapa macam, yaitu:

1. Air suci mensucikan

2. Air suci mensucikan yang makruh.

3. Air yang tercampur dengan benda najis. $^{2}$

Berikut ini adalah penjabarannya secara ringkas:

1.

2.

$1999 \mathrm{M} / 1420 \mathrm{H}$ ), h. 47-52. Lihat juga $\mathrm{H}$ \{asan bin Ahmad bin Muhammad bin Sālim Al-Kāf, alTaqrīrāt al-Sadīdah fi Masā'il al-Mufídah; Qism al'lbādāt, h.57. 


\section{Air suci mensucikan}

Air suci mensucikan disebut dengan air mutlak. Air mutlak adalah keadaan air yang belum mengalami proses apa pun.Air mutlak ini hukumnya suci dan sah untuk digunakan bersuci seperti wudu dan mandi junub. Dalam fikih dikenal dengan istilab țähirün li nafsibi muțabbirun li gairibi. Jenis air kelompok ini jumlahnya banyak, yaitu: ${ }^{3}$

\section{Air Hujan}

Air hujan adalah air yang turun dari langit dalam keadaan cair hingga sampai dibumi. ${ }^{4}$ Hukum air hujan adalah suci dan mensucikan. Suci berarti bukan termasuk najis. Mensucikan berarti bisa digunakan untuk berwudu, mandi janub atau membersihkan najis pada suatu benda.

Kesucinya air hujan telah Allah jabarkan dalam firmannya QS.alAnfāl/8: 11

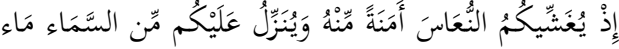

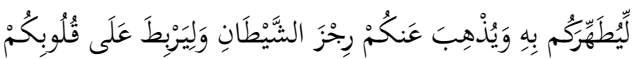

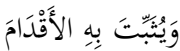

Terjemahnya:

Ketika Allah menjadikan kamu mengantuk sebagai suatu penenteraman daripada-Nya, dan Allah menurunkan kepadamu hujan dari langit untuk mensucikan kamu dengan hujan itu dan menghilangkan dari kamu gangguan-gangguan syaitan dan untuk menguatkan hatimu dan mesmperteguh dengannya telapak kaki. ${ }^{5}$

3lbrahim Al-Baijūrī, Hasyiyah Al-Baijūrī, Juz 1, h. 52-68.

${ }^{4}$ Ibrahim Al-Baijūrī, Hasyiyah Al-Baijūrī, Juz 1, h. 50.

${ }^{5}$ Departemen Agama RI.,al-Qur'an dan Terjemahnya (Madīnah al-Munawwarah: Yayasan Penyelenggara Penterjemah al-Qur'an,
Allah berfirman dalam QS. alFurqān; 25: 48.

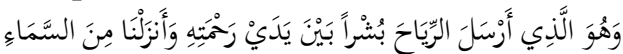

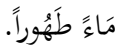

Terjemahnya:

Dia lah yang meniupkan angin pembawa kabar gembira dekat sebelum kedatangan rahmat-nya; dan Kami turunkan dari langit air yang amat bersih. ${ }^{6}$

\section{Air Salju}

Air salju adalah air yang turun dari langit dalam keadaan cair kemudian menjadi padat pada saat sampai dibumi. Salju sebenarnya hampir sama dengan hujan, yaitu samasama air yang turun dari langit, hanya saja kondisi suhu udara yang membuatnya menjadi butir-butir salju yang intinya adalah air juga namun membeku dan jatuh sebagai salju. ${ }^{7}$ Hukumnya tentu saja sama dengan hukum air hujan, sebab keduanya mengalami proses yang mirip kecuali pada bentuk akhirnya saja.

Terdapat hadis Rasulullah saw. yang menjelaskan tentang kedudukan salju, kesuciannya dan juga fungsinya sebagai media menyucian. Dalam doalftitāh setiap salat, salah satu versinya menyebutkan bahwa kita meminta kepada Allah swt. agar disucikan dari dosa dengan air, salju dan embun. Berikut hadisnya:

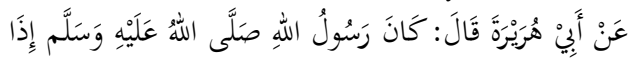

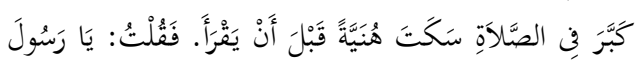

Mujamma' Khādim al-Haramaīn al-Syarīfaīn, alMalik Fahd li Ṭiba'ah al-Mushaf al-Syarīf, $1418 \mathrm{H}$ ), h. 262.

${ }^{6}$ Departemen Agama RI.,al-Qur'an dan Terjemahnya, h. 566.

7lbrahim Al-Baijūrī̄ Hasyiyah Al-Baijūrī, Juz 1, h. 51. 


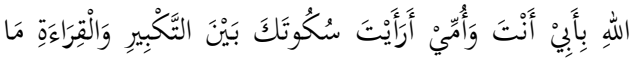

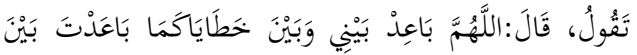

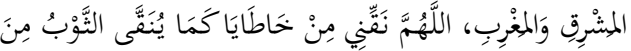

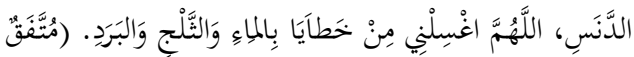

$$
\begin{aligned}
& 8 \text { عَلَيْهِ }
\end{aligned}
$$

Artinya:

Dari Abū Hurairah r.a.berkata: Bahwa Rasulullah saw. jika bertakbir di dalam salat, ia terdiam sebentar sebelum membaca (al-fätihah). Maka aku (Abū Hurairah) bertanya kepadanya: Demi bapak dan ibuku wahai Rasulullah, apa yang kau baca ketika engkaudiam antara takbir dan bacaan (alfätibah)? Nabi menjawab: Aku membaca: Ya Allah, Jauhkan aku dari kesalahn-kesalahanku sebagaimana Engkau menjauhkan antara Timur dan Barat. Ya Allah, sucikan aku dari kesalahan-kesalahanku sebagaimana pakaian dibersihkan dari kotoran. Ya Allah, cucilah aku dari kesalahan-kesalahanku dengan salju, air dan embun. ${ }^{9}$

3. Embun

Embun adalah air yang turun dari langit dalam keadaan padat namun mencair pada saat sampai dibumi. ${ }^{10}$ Embun juga bagian dari air yang turun dari langit, meskipun bukan berbentuk seperti air hujan yang turun dengan deras. Embun lebih merupakan tetestetes air yang akan terlihat banyak di hamparan dedaunan di pagi hari.

${ }^{8}$ Abū 'Abdillāh Muhammad bin Ismā'īl bin Ibrāhīm bin al-Mugīrahal-Bukhārī, Șahīh alBukhārī, No Hadis. 744 (Cet. I;Bairūt: Dār Ibn Kas̀īr, 2002 M/1423 H), h. 184-185. Lihat juga Abū alHuseīn Muslim ibn al-Hajjāj al-Qusyairī alNaisābūrī, Șahīh al-Muslim, Juz. 1, No Hadis. 598 (Cet. I; Bairūt: Dār al-Kutub al-'Ilmiyyah, $1991 \mathrm{M} / 1412$ H), h. 419.
Tetesan embun yang ada pada dedaunan atau pada barang yang suci, bisa digunakan untuk mensucikan, baik untuk berwudu, mandi, atau menghilangkan najis. Dalilnya sama dengan dalil di atas yaitu hadis tentang doa Iftitāh riwayat Abū Hurairah r.a, sebagaimana hadis di atas.

\section{Air Laut}

Air laut adalah air yang suci dan juga mensucikan, sehingga boleh digunakan untuk berwudu, mandi junub, beristinja, dan mensucikan barang, badan dan pakaian yang terkena najis.

Tentang hukum menggunakan air laut sebagai media untuk berwudu, Rasulullah saw. bersabda bahwa air laut itu suci begitu pula bangkainya.

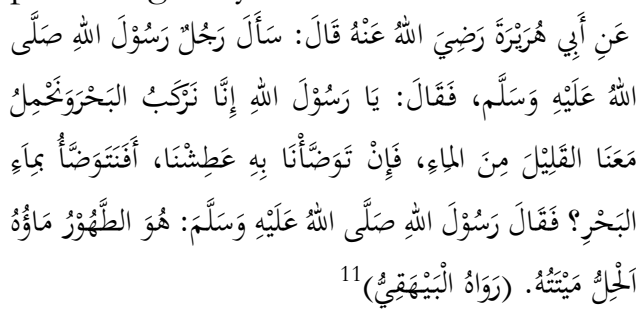

Artinya:

Dari Abū Hurairah r.a.bahwa ada seorang bertanya kepada Rasulullah saw.: Ya Rasulullah, kami mengaruhi lautan dan hanya membawa sedikit air. Kalau kami gunakan untuk berwudu, pastilah kami kehausan.Bolehkah kami berwudu dengan air laut?

${ }^{9}$ HR. Bukhari, No. 744, Muslim, No.

598.

10Ibrahim Al-Baijūrī, Hasyiyah Al-Baijūrī, Juz 1, h. 51.

${ }^{11}$ Abū Bakr Ahmad bin al-Husaīn bin 'Alīal-Baihaqī, al-Sunan al-Kubrī, Jilid. 9 (Cet. III; Bairūt: Dār al-Kutub al-'Il Miyyah, 2003 M), No Hdis. 18674, h. 5-6. 
Rasulullah saw. menjawab: (Laut) itu suci airnya dan halal bangkainya. $^{12}$

Hadis ini sekaligus juga menjelaskan bahwa hewan laut juga halal dimakan walaupun mati menjadi bangkai.

\section{Air Sumur dan Mata Air}

Air sumur adalah air yang dikelurkan dari tanah dengan membuat lubang buatan yang menembus lapisan tanah.Sedangkan mata air adalah air yang keluar secara alami dari permukaan tanah tanpa adanya keterlibatan manusia di dalamnya, baik di dataran rendah maupun tinggi seperti gunung. ${ }^{13}$

Dalil tentang kesucian air sumur atau mata air adalah hadis tentang sumur Bud $\} a>$ 'ah yang terletak di kota Madinah.

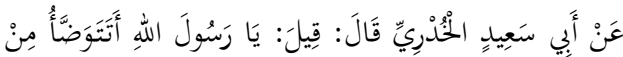

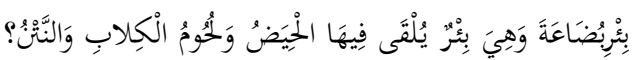

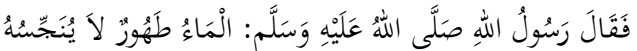

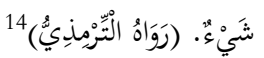

Artinya:

Dari Abi Said Al-Khudhri ra berkata bahwa seorang bertanya,'Ya Rasulullah, Apakah kami boleh berwudhu' dari sumur Budā'ah, padahal sumur itu yang digunakan oleh wanita yang haid, dibuang ke dalamnya daging anjing dan benda yang busuk. Rasulullah saw. menjawab: Air itu suci dan tidak dinajiskan oleh sesuatu.

\section{Air Sungai}

\footnotetext{
${ }^{12}$ HR. Abu Daud, No. 478.

${ }^{13}$ Ibrahim Al-Baijūrī, Hasyiyah Al-Baijūrī,
} Juz 1, h. 51.
Air sungai adalah air tawar yang mengalir lewat belahan bumi. Hukumnya sama dengan air sumur atau mata air. Sejak dahulu umat Islam terbiasa mandi, berwudu dan membersihkan najis termasuk beristinja disungai. Namun air sungai yang tercemar dengan limbah beracun yang meski secara hukum barangkali tidak mengandung najis, namun air yang tercemar dengan logam berat itu sangat berbahaya bagi kesehatan penggunanya, sehingga sebaiknya menghindari penggunaannya, karena memberikan madarat yang lebih besar. Selain itu, sering kali air sungai tercemar dengan limbah kotoran mausia dan ternak, sehingga lamakelamaan airnya berubah warna, bau dan rasanya, maka air sungai tersebut menjadi najis meski jumlahnya banyak melebihi dua Kulah dan tidak sah digunakan untuk berwudu, mandi atau membersihkan najis.

makruh

b. Air suci mensucikan yang

Air suci mensucikan yang makruh yaitu air suci dapat mensucikan namun makruh di gunakan. Air yang masuk dalam kategori ini adalah:

1. Air besuhu panas yang dapat menghalangi kekhusyuan wudu dan mandi.

2. Air besuhu dingin yang dapat menghalangi kekhusyuan wudu dan mandi.

3. Air yang berada pada wilayah yang pernah diturunkan azab Allah. Seperti Bahr al-Mayyit, Wadi Muhassar dan lain-lain.

4. Air musyammas, yaitu air yang menjadi panas atau di panaskan

${ }^{14} \mathrm{Abū}$ 'T̃sā Muhammad bin 'T̃sā AlTirmīzī, al-Jāmi' al-Șahīh\} (Sunan Al-Tirmiżì), Juz 1, No Hadis 66 (Cet. II; t.t.:Muțafā al-Bābī al-Halabī, 1975 M/1395 H.), h. 95-96. 
dengan matahari. Karena penggunaan air musyammasakan menyebabkan penyakit kulit, seperti belang dan kusta. ${ }^{15}$

\section{c. Air Mutanajjis}

Air mutanajjis artinya adalah air yang tercampur dengan barang atau benda najis.Hukum air mutanajjis tidak sah digunakan untuk bersuci dan mengakibatkan najis pada setiap sesuatu yang mengenainya sehingga wajib untuk disucikan kembali.

\section{Hukum Air Hasil Daur Ulang Dari Air Limbah Dan Mutanajjis}

Air daur ulang adalah air hasil olahan (rekayasa teknologi) dari air yang telah digunakan (musta'mal), terkena najis (mutanajjis) atau yang telah berubah salah satu sifatnya, yakni rasa, warna, dan bau (mutagayyir) sehingga dapat dimanfaatkan kembali. ${ }^{16}$

Adapun pembahasan tentang mengenai daur ulang air limbah dan mutanajjis belum pernah terjadi di zaman Rasulullah saw. dan para ulama kelasik terdahulu, hal itu dikarenaka berkaitan dengan teknologi modern. Namun intisari dari praktek ilmiah ini telah tertuang dalam firman Allah QS.al-Nūr/24: 43.

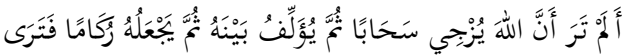

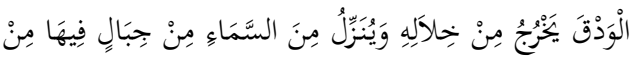

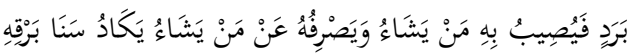

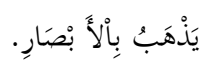

Terjemahnya:

Tidakkah kamu melihat bahwa Allah mengarak awan, kemudian mengumpulkan

${ }^{15}$ Hasan bin Ahmad bin Muhammad bin Sālim Al-Kāf, al-Taqrīrāt al-Sadādah fi Masā'il alMufídah; Qism al-'lbādāt, h. 58.

${ }^{16}$ Majelis Ulama Indonesia Propinsi Jawa Timur, Fatwa MUI: Air Daur Ulang, antara (bagian-bagian) nya, kemudian menjadikannya bertindih-tindih, maka kelihatanlah olehmu hujan keluar dari celah-celahnya dan Allah (juga) menurunkan (butiran-butiran) es dari langit, (yaitu) dari (gumpalangumpalan awan seperti) gunung-gunung, maka ditimpakan-Nya (butiranbutiran) es itu kepada siapa yang dikehendaki-Nya dan dipalingkan-Nya dari siapa yang dikehendaki-Nya. Kilauan kilat awan itu hampirhampir menghilangkan penglihatan. ${ }^{17}$

Melalui ayat tersebut air laut yang asin dapat menjadi air tawar setelah diolah diawan yang berlapislapis.Metode istibälah dalam menjadikan air yang mengalami perubahan pada rasa, bau dan warnanya karena sesuatu yang najis atau suci dapat dilakukan dengan tiga cara, yaitu:

1. Mukaṡṡarah, yaitu menambahkan air yang suci kepadanya, sehingga menjadi dua Kulah dan hilang sifat najisnya atau benda sucinya, yaitu rasa, warna atau aromanya.

2. Nazh, yaitu mengurangi air tersebut akan tetapi air yang tersisa tidak kurang dari dua Kulah.

3. Mukus, yaitu perubahan tersebut hilang dengan sendirinya secara alamiah. Hal itu disebabkan oleh beberapa factor, di antaranya pengendapan yang lama, atau terik

http://muijatim.org/index.php/12-fatwa-mui2010/37-fatwa-mui-air-daur-ulang. (Diakses 02/05/2016)

${ }^{17}$ Departemen Agama RI.,al-Qur'an dan Terjemahnya, h. 551-552. 
matahari, atau hembusan angin, atau yang semisal dengannya. ${ }^{18}$

4. Tagyìr, yaitu dengan cara mengubah air yang terkena najis atau yang telah berubah sifatnya tersebut dengan menggunakan alat bantu yang dapat mengembalikan sifat-sifat asli air itu menjadi suci lagi mensucikan (țähir mutabbir), dengan syarat:

a. Volume air lebih dari dua kulah;

b. Alat bantu yang digunakan harus suci;

c. Dapat dipastikan berdasarkan penelitian tidak mengandung halhal yang membahayakan kesehatan. ${ }^{19}$

Seiring dengan peningkatan pesat kebutuhan air dan penurunan kualitas sumber air akibat dari peningkatan jumlah penduduk, laju urbanisasi dan perkembangan industry maka MUI melalui fatwanya tentang Air Daur Ulang Nomor: 02 Tahun 2010menetapkan bahwa air daur ulang yang semula berasal dari limbah yang bercampur dengan kotoran, benda najis, dan komponen lain yang merubah kemutlakan air dapat dipakai untuk menghilangkan hadas dan najis, diminum dan lain-lain, selama dijamin tidak membahayakan kesehatan. ${ }^{20}$

Menurut Kepmenkes No.907/Menkes/VII/2002 tentang Syarat dan Pengawasan Kualitas Air Minum yang dikutip oleh Nusa Idaman Said dari Pusat Pengkajian dan Penerapan Teknologi BPPT, air minum itu harus bebas dari bahan-

${ }^{18}$ Hasan bin Ahmad bin Muhammad bin Sālim Al-Kāf, al-Taqrīrāt al-Sadīdah fi Masīil alMufídah; Qism al-'Ibādāt, h. 64.

${ }^{19}$ Majelis Ulama Indonesia Propinsi Jawa Timur, Fatwa MUI: Air Daur Ulang, http://muijatim.org/index.php/12-fatwa-mui2010/37-fatwa-mui-air-daur-ulang. (Diakses 02/05/2016) bahan organik dan anorganik, bebas dari zat kimia, racun, limbah berbahaya dan sebagainya. ${ }^{21}$

Dengan demikian dapat disimpulkan, bahwa air daur ulang, baik menurut pandangan fukaha klasik maupun kontemporer hukumnya adalah suci dan mensucikan serta halal untuk dikonsumsi, dengan catatan berdasarkan uji laboratorium benarbenar dijamin tidak membahayakan kesehatan manusia.

Persyaratan bahwa air itu tidak membahayakan kesehatan oleh keputusan Fatwa MUI tentang Air Daur Ulang yang menjadi syarat bagi țähir muțahbir-nya air daur ulang sejalan dengan Kepmenkes. Oleh karena itu, hal ini harus dijadikan acuan secara konsisten untuk menentukan hukum air daur ulang. Apabila kriteria tersebut terpenuhi maka tidak perlu ragu menyatakan bahwa air daur ulang jelas țāhir muțabhir dan halälan țayyiban.

\section{PENUTUP}

Berdasarkan pembahasan di atas, maka dapat disimpulkan bahwa:

Dalam ilmu fikih, air terbagi menjadi empat macam, yaitu:

a. Air suci mensucikan.

b. Air suci mensucikan yang makruh

c. Air yang tercampur dengan benda najis.

d. Air limbah dan mutanajjis menjadi air suci dan mensucikan(țäbirun wa

\footnotetext{
${ }^{20}$ Majelis Ulama Indonesia Propinsi Jawa Timur, Fatwa MUI: Air Daur Ulang, http://muijatim.org/index.php/12-fatwa-mui2010/37-fatwa-mui-air-daur-ulang. (Diakses 02/05/2016)

${ }^{21} \mathrm{Ahmad}$ Munif Suratmaputra, Hukum Air Daur Ulang, http://www.iiq.ac.id/index.php?a=artikel $\& d=2 \& i$ $d=42$. (Diakses 02/05/2016)
} 
mutabhirun) setelah melalui proses yang ada.

\section{DAFTAR PUSTAKA}

Al Quran Al Karim

Al-'Asqalānī, Ahmad bin 'Al̄̄ Ibn Hajar. Bulüg al-Marām min Adillat al-Abkäm.Cet. I; Bairūt: Dār Ihyā' al-'Ulūm, $1991 \mathrm{M} / 1421 \mathrm{H}$.

Al-Baihaqī, Abū Bakr Ahmad bin alHusain bin 'Alī. Al-Sunan alKubrā. Cet. III; Bairūt: Dār alKutub al-'Il Miyyah, 2003 M.

Al-Baijūrī, Ibrāhīm.Hasyiyah Al-Baijūrì. Cet. II; Bairūt: Dār Al-Kutub al-'Ilmiyyah, 1999 M/1420 H.

Al-Bukhārī, Abū 'Abdillāh Muhammad bin Ismā'îl bin Ibrāhīm bin alMugīrah. Sabìh al-Bukhärì. Cet. I; Bairūt: Dār Ibn Kas̀īr, $2002 \mathrm{M} / 1423 \mathrm{H}$.

Al-Jauziyyah, Syams al-Dīn Abū'Abdullāh Muhammad Ibn Abī Bakr Ibnu Qayyim. I'làm al-Munuaqi ìn 'An Rabb alÁlaminn.Bairūt: Dār al-Kutub al-'Ilmiyyah, $1993 \mathrm{M}$.

Al-Kāf, Hasan bin Ahmad bin Muhammad bin Sālim. AlTaqrīràt al-Sadìdah fi Masāil alMufìdab; Qism al-Tbādāt. Cet. I; Tarīm: Dār al-'Ilm wa alDa'wah, 1423 H/2003 M.

Al-Naisābūrī, Abū al-Husein Muslim bin al-Hajjāj al-Qusyairī. Sabīh Muslim. Cet. I; Bairūt: Dār al-Kutub al-'Ilmiyyah, $1991 \mathrm{M} / 1412 \mathrm{H}$.

Al-Tirmiżī, Abū 'Īsā Muhammad bin 'Īsā.Al-Jāmi' al-Ṣabīb(Sunan Al-Tirmizi). Cet. II; t.t.: Mușțafā al-Bābī al-Halabī, $1975 \mathrm{M} / 1395 \mathrm{H}$.

Departemen Agama RI. al-Qur'an dan Terjemahnya. Madīnah al-
Munawwarah: Yayasan Penyelenggara Penterjemah al-Qur'an, Mujamma“ Khādim al-Haramain alSyarīfain, al-Malik Fahd li Țiba'ah al-Muṣhaf al-Syarāf, $1418 \mathrm{H}$.

Majelis Ulama Indonesia Propinsi Jawa Timur. Fatwa MUI: Air Daur Ulang.

http:/ / muijatim.org/index.p hp/12-fatwa-mui-2010/37fatwa-mui-air-daur-ulang. (Diakses 02/05/2016)

Suratmaputra, Ahmad Munif. Hukum Air Daur Ulang. http://www.iiq.ac.id/index.p hp $? \mathrm{a}=$ artikel\&d $=2 \& \mathrm{id}=42$. (Diakses 02/05/2016) 